\title{
Basal cell carcinoma arising in a smallpox vaccination site
}

\author{
JD RICH, BF SHESOL, AND DW HORNE, III \\ From Fitzsimons Army Medical Center, Denver, Colorado 80240, USA
}

SUMmARY A case of pigmented basal cell carcinoma developing in a smallpox revaccination site is presented. Any progressive change within a smallpox vaccination scar should be thoroughly evaluated and treated appropriately after tissue diagnosis.

Malignant change in post-traumatic scars appears with a clinically significant frequency, most notably squamous cell carcinoma arising in burn scars of long-standing duration. In addition, a variety of other malignant tumours have been reported in chronically traumatised skin. ${ }^{1-3}$ Malignant change in smallpox vaccination scars has been infrequently described in the world medical literature. ${ }^{5}$ According to Kulwin ${ }^{6}$ a total of 54 cases have been reported, of which 31 were basal cell carcinomas, nine were squamous cell carcinomas, and a surprising $13(24 \%)$ were malignant melanomas. A review of the histological types of basal cell carcinomas arising in smallpox vaccination scars revealed only two being described as pigmented. ${ }^{7}$ The patients' ages ranged from 40 to 60 years, and in most cases vaccination had been performed more than 30 years before the appearance of the lesion. A case terminating in death was reported by Dorsey et al. ${ }^{8}$

\section{Case report}

A 56-year-old Caucasian woman was revaccinated in the left deltoid area in July 1974. She had been initially vaccinated in 1969 in the right deltoid area. Shortly after the disappearance of the characteristic crusting from the vaccination site a slightly irregular, raised area appeared which very gradually increased in size. Four and one-half years later the patient was seen and noted to have a $2 \frac{1}{2} \times 3 \mathrm{~cm}$ irregularly pigmented, exophytic lesion on the left upper arm with a central area of ulceration (Fig. 1). Upon careful questioning the patient stated emphatically that the lesion had arisen in precisely the location of the revaccination. No other scars were visible on the deltoid region.

Received for publication 31 July 1979
No nodes were palpable in the left axilla. The lesion was excised with a $1 \mathrm{~cm}$ margin, and primary closure was accomplished. Satisfactory wound healing ensued.

Histological examination of the specimen revealed a basal cell carcinoma with underlying inflammation (Fig. 2). A central area of ulceration was noted, and a moderate degree of pigment was present within the tumour. The final diagnosis was pigmented basal cell carcinoma. All margins were free of neoplasm.

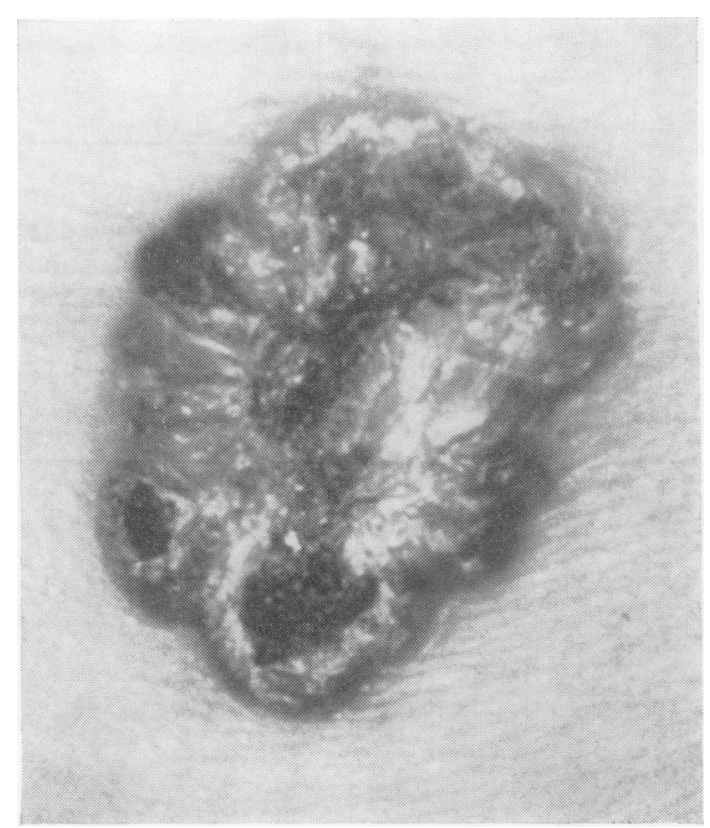

Fig. 1 Clinical appearance of lesion appearing in smallpox vaccination site. 


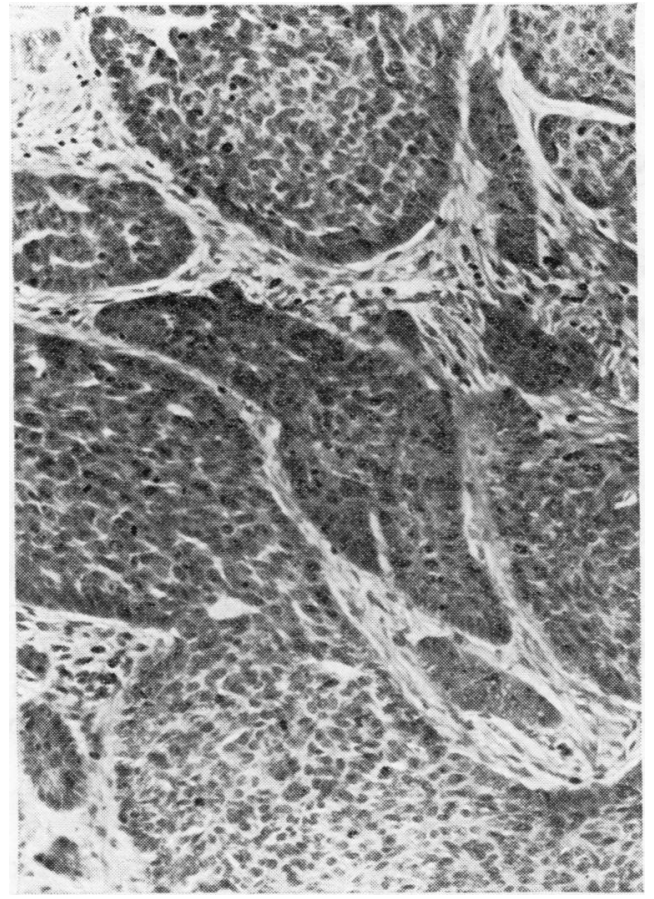

Fig. 2 Basaloid cells, peripheral palisading, and frequent mitoses.

\section{Discussion}

A variety of malignant tumours have been described arising in vaccination sites. Marmelzat ${ }^{9}$ described $^{2}$ the various aetiological factors associated with his reported cases, including the effect of the vaccinia virus, possible contact carcinogens, and the recognised carcinogenic potential in scar tissue. It is well recognised that live viruses can play an inductive role in the formation of tumours in experimental animals. ${ }^{10}$ Lokich $^{11}$ observed a malignant melanoma arising in a BCG scarification site. It is interesting to speculate concerning the possible aetiological role of the vaccinia virus in regard to malignant change within the vaccination scar.

The opinions or assertions contained herein are the private views of the authors and are not to be construed as official or as reflecting the views of the Department of the Army or the Department of Defense.

\section{References}

${ }^{1}$ Lever W F, Schaumburg-Lever G. Histopathology of the Skin. 5th ed. Philadelphia: J B Lippincott, 1975.

${ }^{2}$ Arons M S, Lynch J B, Lewis S R, Blocker T G Jr. Scar tissue carcinoma. Part 1. A clinical study with special reference to burn scar carcinoma. Ann Surg 1965; 161 : 170-188.

${ }^{3}$ Engler H S, Fernandez A, Bliven F E, Moretz W H. Cancer arising in scars of old burns and in chronic osteomyelitis, ulcers, and drainage sites. Surgery 1964; 55: 654-664.

${ }^{4}$ Auger C. Cancer sur tatouage et cancer sur cicatrice de vaccination antivariolique. Lav Med 1943; 8: 300-307.

${ }^{5}$ Rea E. Squamous carcinoma on vaccination scar. $S$ Afr Med J 1956; 30: 499.

${ }^{6} \mathrm{Kulwin} \mathbf{M} \mathbf{H}$. Basal cell epithelioma in smallpox vaccination scar-fifty years later. Ill Med J 1975; 148: 612-613.

${ }^{7}$ Goncalves J C A. Malignant change in smallpox vaccination scars. Arch Derm 1966; 93: 229-230.

${ }^{8}$ Dorsey C S, Marmelzat W, Levan N. Skin cancer in smallpox vaccination scars: a report of five cases. Calif Med 1960; 92: 353.

${ }^{9}$ Marmelzat W L. Malignant tumors in smallpox vaccination scars. Arch Derm 1968; 97: 400-406.

${ }^{10}$ Mazurenko N P. Induction of leucoses in mice with infectious viruses and the significance of the latter in the etiology of disease. Probl Oncol 1960; 6: 873-882.

${ }^{11}$ Lokich J J. (Letter) Malignant melanoma arising de novo within a BCG scarification site. Lancet 1975; 1: 331-332.

Requests for reprints to: Dr J D Rich, Colonel, MC, Chief, Plastic Surgery Service, Department of the Army, Fitzsimons Army Medical Center, Denver, Colorado 80240, USA. 